\title{
Impairment of cytomegalovirus-specific cellular immune response as a risk factor for cytomegalovirus disease in transplant recipients
}

\author{
V.N. Motta and S.L.R. Martins \\ Fleury Medicina e Saúde, São Paulo, SP, Brasil \\ Correspondence to: V.N. Motta, Instituto Fleury, Rua Gen. Valdomiro Lima, 508, 04344-903 São Paulo, \\ SP, Brasil \\ E-mail: vinicius.n.motta@gmail.com
}

\begin{abstract}
Human cytomegalovirus (CMV) infection is common in most people but nearly asymptomatic in immunocompetent individuals. After primary infection the virus persists throughout life in a latent form in a variety of tissues, particularly in precursor cells of the monocytic lineage. CMV reinfection and occurrence of disease are associated with immunosuppressive conditions. Solid organ and bone marrow transplant patients are at high risk for CMV disease as they undergo immunosuppression. Antiviral treatment is effective in controlling viremia, but $10-15 \%$ of infected patients can experience CMV disease by the time the drug is withdrawn. In addition, long-term antiviral treatment leads to bone marrow ablation and renal toxicity. Furthermore, control of chronic CMV infection in transplant recipients appears to be dependent on the proper recovery of cellular immunity. Recent advances in the characterization of T-cell functions and identification of distinct functional signatures of T-cell viral responses have opened new perspectives for monitoring transplant individuals at risk of developing CMV disease.
\end{abstract}

Key words: Cytomegalovirus infection; T-cell responses; Transplant recipients; Intracellular cytokines

Publication supported by FAPESP.

Received December 20, 2006. Accepted August 27, 2007

\section{INTRODUCTION}

Cytomegalovirus (CMV) is a genus of the ß-herpes virinae subfamily of Herpesviridae, a double-strand DNA $230-\mathrm{kb}$ virus that produces more than 200 proteins. These proteins are produced in three overlapping phases: immediate early (IE), early, and late (1). Human infection usually peaks first during childhood and results from both vertical and horizontal transmission after virus shedding in urine and in respiratory secretions. The next peak occurs in young adults, mostly by sexual transmission and 50 to more than $90 \%$ of the worldwide population become seropositive for CMV throughout life.

Primary CMV infection is commonly asymptomatic in healthy and immunocompetent individuals but can produce fever, myalgia, pharyngitis, cervical lymphadenopathy, mild hepatitis, and spleen enlargement as a mononucleosis-like illness (2). After primary infection, CMV is not completely eliminated from the host but remains latent in a variety of tissues, particularly within macrophages, granulocytes and dendritic cell precursors (3). In contrast, reactivation of the virus with severe clinical symptoms is commonly observed in immunocompromised hosts $(4,5)$. Leukopenia, pneumonitis, retinitis, encephalitis, and gastrointestinal problems are frequently observed in these patients.

Reactivation of CMV is not completely understood but a series of mechanisms, which have in common the cAMP and NFKB pathways, are likely to play a role, such as stress, inflammation and some cAMP-elevating drugs. These mechanisms lead to activation of the CMV IE enhancer/promoter that initiates virus replication (6).

Immunologic control of CMV replication includes several 
distinct categories of effector cells: natural killer cells, macrophages, B cells, $\gamma \delta$ and $\alpha \beta$ T cells. In most circumstances, however, virus-specific $\mathrm{CD}^{+}$and $\mathrm{CD}^{+} \mathrm{T}$ cells appear to play a pivotal role (7-9).

\section{THE RISK FOR CMV REACTIVATION AND REINFECTION IN TRANSPLANT RECIPIENTS}

Transplant recipients usually are immunosuppressed and are at high risk of developing CMV diseases. The risk is associated with the degree of T-cell functional impairment and the mode and magnitude of immunosuppression. The serological CMV status of pretransplant donor and recipient $(D / R)$ also correlates with both the incidence and severity of disease. Seronegative recipients of a CMVpositive organ $\left(D^{+} / R^{-}\right)$will develop primary infection. Despite successful treatment, CMV infection recurs in one third of solid organ recipients (10). Of note, the secondary consequences of CMV infection are: enhanced susceptibility to post-transplant Epstein Barr virus-related lymphoproliferation (11), acute chronic allograft rejection (12), and opportunistic infections (4).

The relationship between the risk for CMV disease and the serologic CMV status of $D / R$ is the reverse in stem cell and bone marrow transplants (BMT). Seronegative recipients of CMV-positive donor bone marrow $\left(\mathrm{D}^{+} / \mathrm{R}^{-}\right)$are not at higher risk of developing CMV disease, while seropositive recipients of seronegative bone marrow donors $\left(\mathrm{D}^{-} / \mathrm{R}^{+}\right)$are at an increased risk for reinfection $(13,14)$. The least risk for CMV infections in BMT occurs when both donor and recipient are CMV seronegative pre-transplant $\left(D^{-} / R^{-}\right)(15)$. It is thought that the remaining CMV-specific T cells transferred along with the bone marrow of seropositive $\left(D^{+}\right)$but not with seronegative $\left(D^{-}\right)$donors confer protection against the recipient's $\left(R^{+}\right)$own CMV reactivation $(14,16,17)$. The risk of developing CMV disease is also higher for stem cell transplant and BMT recipients from unrelated and haploidentical donors $(18,19)$. In this case, the risk for CMVdisease is likely to be linked to the predisposition for graftversus-host-disease complications. Graft-versus-host-disease culminates with T-cell functional impairment, as also does CMV-specific cell immunity (14).

\section{CLINICAL MANAGEMENT OF TRANSPLANT RECIPIENTS AT RISK OF DEVELOPING CMV DISEASE}

Before the era of antiviral drugs the only treatment for CMV infection was reduction of immunosuppression in transplant recipients. The development of drugs able to inhibit the viral DNA polymerase activity (Forscanet), or nucleoside analogues (acyclovir, valganciclovir and ganciclovir) that inhibit the incorporation of dGTP terminating the elongation of viral DNA $(20,21)$ has led to improved antiCMV disease therapies.

The prophylaxis strategy, in which all transplant recipients are treated with antiviral drugs before and up to 3 months after transplantation, has significantly decreased the incidence of disease as compared with placebo or no treatment (22). However, long-term prophylaxis with antiviral drugs is myeloablative and nephrotoxic, and can be associated with delayed CMV-specific T-cell immunity recovery, drug resistance and late-onset CMV disease $(9,23,24)$. Besides, unnecessary treatment of individuals that may not develop disease is not desired. Hence, the role of prophylaxis has been questioned in favor of pre-emptive therapy (25). This approach involves antiviral drug therapy for patients known to be at risk for active or severe disease on the basis of an epidemiological or biological marker. Instead of being administered to all transplant recipients, anti-CMV drugs can be selectively given to the at-risk population saving costs and reducing toxicity.

Biomarkers able to identify patients at risk of developing CMV disease before the onset of the disease are crucial for preemptive therapy. Early on, shell vial cultures of bronchoalveolar lavage for CMV detection were used as a strategy to identify CMV-positive transplant recipients at risk (26). The preemptive approach has benefited enormously from advances in CMV diagnosis. The pp65 antigenemia and the widespread application of PCR methodology have provided clinicians with the means of monitoring CMV activity more accurately and to identify groups of patients at risk of developing disease $(5,13,27)$. One weakness of the preemptive therapy, however, is that CMV activity may be detected just before, at the same time as or after the manifestation of disease and the treatment may not be efficient. In addition, CMV viral load is not universally associated with disease and some patients may develop CMV disease without testing positive for CMV $(26,28,29)$. An explanation might be linked to the status of the host's antiviral cellular immunity (30). As we shall discuss next, there is evidence that the pattern of CMVspecific T-cell immunity is an independent risk factor for CMV disease in transplant recipients $(31,32)$.

\section{T-CELL PHENOTYPE AND FUNCTIONAL SIGNATURES FOR THE CLINICAL MONITORING SETTING}

The role of $T$ cells in anti-viral immunity has been known for a long time (8). T lymphocytes are important in the early and late stages of virus infections $(7,33)$. Upon viral infection the host responds with both the innate and adaptive arms of the immune system. The adaptive immune response is characterized by activation of viral spe- 
cific T-cell clones that differentiate into effector and memory $\mathrm{T}$ cells. Memory $\mathrm{T}$ cells play an important role in secondary infections when they quickly differentiate into effector cells promoting faster, stronger and more efficient responses against the infectious agent. In the absence of memory $\mathrm{T}$ cells, the host is at risk of developing viral disease and severe clinical symptoms. Over the past 5-10 years, conceptual and technical advances have substantially improved T-cell assays for the determination of the phenotypes and functional signatures of memory and effector $\mathrm{T}$ cells. It is now possible to functionally characterize $\mathrm{T}$ cell immunity that might be suitable for both diagnosis and clinical monitoring $(30,34,35)$.

In their landmark paper, Sallusto et al. (36) characterized two phenotypically and functionally distinct memory $\mathrm{T}$ cells for both CD4 and CD8 T cells. CCR7- T cells preferentially secrete cytokines IL-4, IL-5 and IFN- $\gamma$, and because they lose the expression of CCR7 (a receptor homing to lymph nodes) are prone to circulate into inflamed tissues, and $\mathrm{CCR}^{+}$memory $\mathrm{T}$ cells that secrete IL-2 and seed lymph nodes and spleen. They were classified as effector memory T cells (CCR7-) and central memory T cells (CCR7 $\left.{ }^{+}\right)$. CD57, CD62L, CD28, CD27, and CD45RA surface markers have also been used to characterize these distinct memory $\mathrm{T}$-cell subpopulations and the CD45RA+ CD27- T-cell phenotypes are thought to be fully differentiated cells exhibiting shorter telomere length $(37,38)$. Loss of CD27 and expression of CD45RA in a varying proportion of CMV-specific CD8 T cells are associated with spontaneous IFN- $\gamma$ secretion and may be a correlate with in vivo virus activity $(38,39)$.

Early studies measured intracellular cytokines in response to CMV viral lysates and revealed percentages of cytokine-secreting $T$ cells in seropositive but not in seronegative individuals (40), though with great variation among the seropositive individuals (41). A hierarchy of cytokinepositive $\mathrm{T}$ cells (TNF- $\alpha>\mathrm{IFN}-\gamma>\mathrm{IL}-2)$ can be seen in chronic CMV infection $(42,43)$. Interestingly, high TNF- $\alpha$ secreting cells are also high IFN- $\gamma$-producing cells, but this correlation is not observed for IL-2-secreting cells (30). Indeed, a distinct role in viral immunity related to the ability of $\mathrm{T}$ cells to secrete IL-2 and/or IFN- $\gamma$ has been proposed. The presence of viral specific IFN- $\gamma$-secreting cells alone defines an acute infection with a high viral antigen load; conversely, the existence of cells producing IL-2 alone, IFN- $\gamma$ alone or IL-2 plus IFN- $\gamma$ correlates with chronic infection with low levels of viral antigen.

Using tetramer conjugated peptide, Bunde et al. (44) have recently suggested that protection from CMV infection is correlated with IE-1-specific but not with pp65specific CD8 T cells in transplant recipients. However, other studies have shown pp65-specific T cells as inde- pendent risk factor for CMV disease and long-term virus control in such patients $(16,45-49)$. Transplant recipients with levels of $\mathrm{CMV}$-specific $\mathrm{CD}^{+} \mathrm{T}$ lymphocytes above 0.2-1 $\times 10^{7}$ cells per liter do not develop CMV disease $(16,45)$.

CD4 T cells, on the other hand, are necessary to initiate and maintain CMV CD8-effector immune response as clearly demonstrated on adoptive cellular immunotherapy $(16,32,48)$.

Functional analysis of the cell immune response appears, however, to be a better biomarker for disease risk than the number of CMV-specific T cells $(48,50)$. Quinnan et. al. (8) showed as early as in the 1980's the correlation between the presence of CMV-specific cytotoxic $\mathrm{T}$ cells and protection from CMV infection. Absence of lymphocyte proliferation in response to CMV antigens in vitro was another risk factor for disease (31). Until recently, it has been difficult to assess $\mathrm{T}$-cell functional immunity given the complexity of T-cell manipulation, which involves isolation of mononuclear cells from large volumes of biological specimens and careful storage of viable samples. Thus, there has been limited interest in assessing the use and importance of measuring T-cell function in diagnostic and clinical monitoring settings. However, the possibility of assessing T-cell functionality within just about $6 \mathrm{~h}$ directly on a fresh whole blood specimen (42) has increased the interest in studying the CMV-specific immune response as a risk factor for CMV disease in transplant recipients (16,45-49). In parallel, a relatively simple procedure for the isolation, in vitro expansion and transfer of CMV-specific $\mathrm{T}$ cells into patients has been pursued as therapy for patients at risk of developing CMV disease (51).

\section{METHODOLOGICAL ADVANCES IN CYTOKINE FLOW CYTOMETRY}

CMV-specific $T$ cells can be functionally assessed by cytokine and chemokine release, cytotoxic potential and T-cell proliferation. Enzyme-linked immunosorbent spot can enumerate cytokine-secreting CMV-specific $\mathrm{T}$ cells upon in vitro stimulation with viral antigens $(46,52)$. However, assessment of CMV-specific T-cell function by polychromatic flow cytometry enables simultaneously assessment of several functions, including cytokine secretion (intracellular staining), cytotoxic potential (as measured by perforin expression and degranulation activity) and permits the visualization of proliferating $T$ cells based on the use of a dye, carboxyfluorescein succinimidyl ester. Besides, flow cytometry allows to phenotype the T-cell population responding to the stimulus. Over the past 5 years, there has been great interest in the quantification of cytokine production by flow cytometry, referred to as cytokine 
flow cytometry, which is now in advanced stages of standardization (53). Important achievement is the possibility to use fresh whole blood or frozen peripheral blood mononuclear cells, which allows direct processing with minimal manipulation, sample shipment, storage, and latter processing (54). In addition, 96-well plate-based assays, rather than 15-mL tubes, allow high throughput of samples and are suitable for the clinical settings (55). Moreover, whole blood samples can be processed in 96-deep-well plates ( 2 $\mathrm{mL}$ ), in which the entire staining procedure can be per- formed, including the lysis of red cells, without the need of sample transferring. Stimulation is usually performed for short time, 6-8 $\mathrm{h}$ that allows sample collection, processing and analysis on a single day. Besides, automate water bath can be set up to cool samples down to $4^{\circ} \mathrm{C}$ overnight, by which samples can be processed on the next day (42).

Briefly, cytokine flow cytometry consists of activating whole blood or peripheral blood mononuclear cells in vitro for $6 \mathrm{~h}$ to induce the production of effector cytokines such as IFN- $\gamma$ or TNF- $\alpha$. The antigen may be a single peptide or

\section{A}
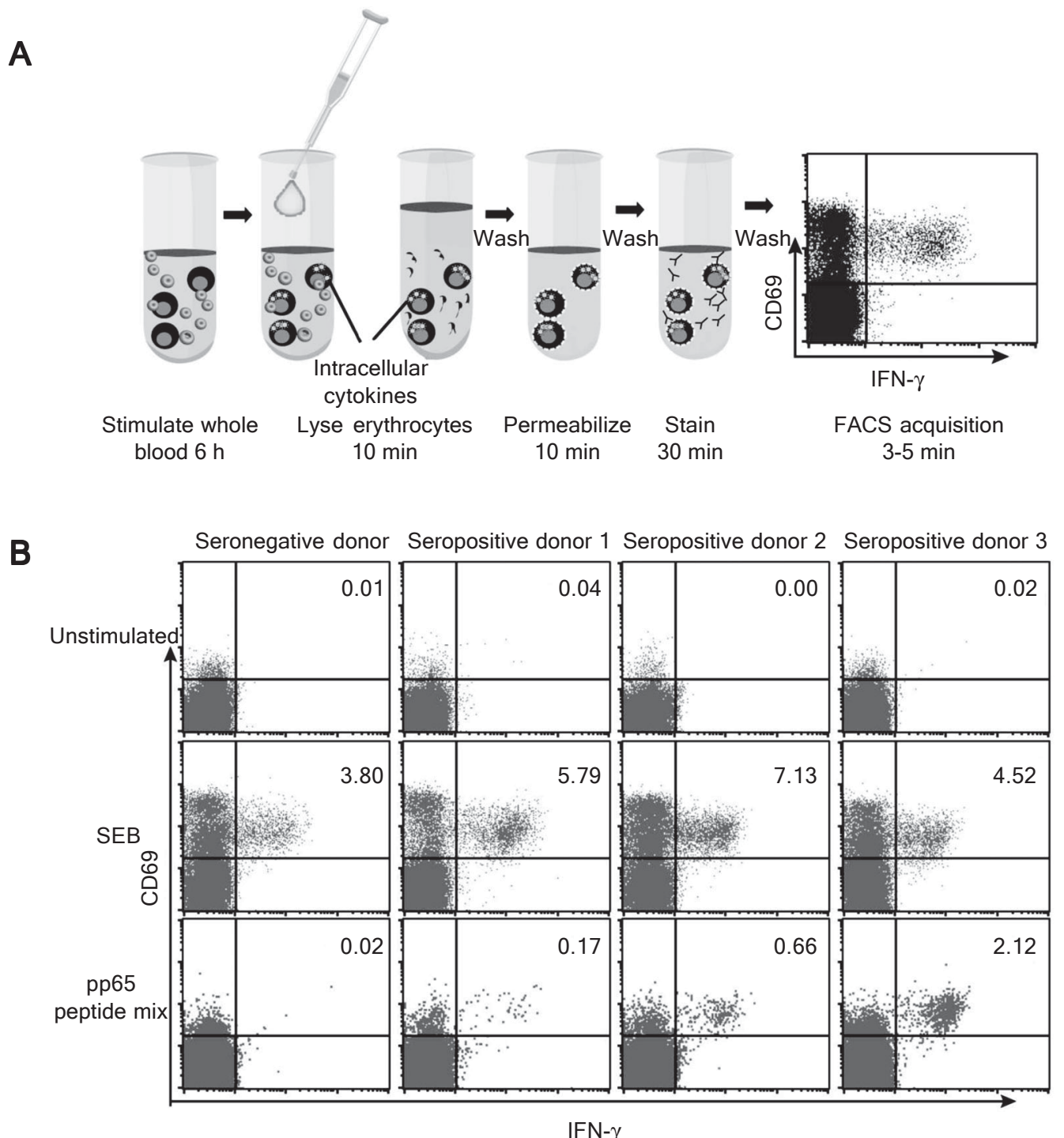

Figure 1. Intracellular cytokine flow cytometry. A, Schematic illustration and estimated time for each step required for stimulation and detection of intracellular cytokine in whole blood samples. Lysing buffer is added directly to blood (adapted from Ref. 57, with permission). B, Typical quantitative assay of cytomegalovitus (CMV)-specific IFN- $\gamma$-secreting $\mathrm{CD}^{+}{ }^{+} \mathrm{T}$ cells. Whole blood samples were left unstimulated (negative control) or were stimulated with SEB (positive control) or with a mixture of 15-amino acid and 11amino acid peptides with overlaps spanning the CMV glycoprotein pp65. Specificity and sensitivity for the detection of CMV-specific activated T cells are shown by the absence of IFN- $\gamma^{+}$cells in the seronegative donor, and by low-, medium- and high-responder seropositive donors (B, lower panel). 
a pool of peptides $(56,57)$, purified virus antigenic polypeptides (58) or even virus-infected cell lysates (43). The addition of a transport inhibitor such as Brefeldin A prevents secretion and causes cytokine accumulation in the cytoplasm (59). Then, intracellular cytokine staining is performed and cells are analyzed by flow cytometry (Figure 1). This allows a qualitative and quantitative assessment of CMV immunity in patients. Co-staining with CD4, CD8 and MHC-tetramers makes it possible to determine the proportion of tetramer-binding T-cell subsets that respond to stimulation (47).

CD4 T-cell response to CMV is more effective when viral lysates are used, whereas the use of peptides permits a more consistent detection of CD8 T-cell responses $(56,57,60)$. However, protein-spanning pools of overlapping peptides have been shown to stimulate both CD4 and CD8 T-cell responses to CMV in the same sample when peptides of the appropriate length (15 amino acids) and overlap (11 amino acids) are used $(57,60)$.

\section{CONCLUDING REMARKS}

At present, prophylaxis and preemptive antiviral drug treatment are the most reliable treatment for the prevention of CMV disease in transplant recipients. However, these treatments appear to act as a double-edged sword, leading to a decrease in infection but also to an increase in late-onset drug-resistant CMV disease. Besides, long-term drug treatment has adverse side effects and $5-10 \%$ of transplant recipients progress to end-organ CMV disease. Therefore, cell-based immunotherapy and alternative clinical monitoring are desired to manage not only CMV-infected patients but also patients at risk for other viral diseases. The presence of CMV-specific CD4 and CD8 multifunctional T-cell responses indicates efficient control of virus replication. Furthermore, alterations in functional signatures of T cells may detect subtle changes of virus replication activity before detectable levels are reached in the host.

The use of cytokine flow cytometry in clinical settings is expected to be cost-effective. Flow cytometry is already a well-established method widely applied in leukemia diagnosis and immunophenotyping. The costs of cytokine flow cytometry should not be higher than those of other T-cell functional assays, such as the measurement of cell proliferation by thymidine incorporation. In addition, this procedure does not require duplicate or triplicate samples, being very sensitive and specific. The possibility of directly processing whole blood for T-cell stimulation makes the assay less time consuming, with just one additional step in comparison to conventional intracellular leukemia panels, such as TDT, CD3 and immunoglobulin light/heavy chains. Nonetheless, we lack well-designed studies comparing the cost effectiveness of cytokine flow cytometry with other methodologies for monitoring patients at risk of developing CMV disease. Furthermore, standardization of cytokine flow cytometry and well-designed and controlled studies are necessary for a better understanding of the correlation of certain functional T-cell signatures with protection from $\mathrm{CMV}$ disease. At present, quantification of IFN- $\gamma$-secreting $\mathrm{T}$ cells has been associated with risk of developing CMV disease in transplant recipients. However, additional information on distinct T-cell functional signatures might improve diagnosis and deserves further investigation.

In conclusion, functional signatures of T-cell responses can represent sensitive measures of viral activity and may be useful tools for monitoring CMV-associated disease activity in clinical settings.

\section{REFERENCES}

1. McDonough SH, Spector DH. Transcription in human fibroblasts permissively infected by human cytomegalovirus strain AD169. Virology 1983; 125: 31-46.

2. Sissons JG, Carmichael AJ. Clinical aspects and management of cytomegalovirus infection. J Infect 2002; 44: 78-83.

3. Hahn G, Jores R, Mocarski ES. Cytomegalovirus remains latent in a common precursor of dendritic and myeloid cells. Proc Natl Acad Sci U S A 1998; 95: 3937-3942.

4. Fishman JA, Rubin $\mathrm{RH}$. Infection in organ-transplant recipients. N Engl J Med 1998; 338: 1741-1751.

5. Yakushiji K, Gondo H, Kamezaki K, Shigematsu K, Hayashi $\mathrm{S}$, Kuroiwa $\mathrm{M}$, et al. Monitoring of cytomegalovirus reactivation after allogeneic stem cell transplantation: comparison of an antigenemia assay and quantitative real-time polymerase chain reaction. Bone Marrow Transplant 2002; 29: 599606.

6. Reinke P, Prosch S, Kern F, Volk HD. Mechanisms of human cytomegalovirus (HCMV) (re)activation and its impact on organ transplant patients. Transpl Infect Dis 1999; 1: 157164.

7. Doherty PC, Allan W, Eichelberger M, Carding SR. Roles of alpha beta and gamma delta T cell subsets in viral immunity. Annu Rev Immunol 1992; 10: 123-151.

8. Quinnan GV Jr, Kirmani N, Rook AH, Manischewitz JF, Jackson L, Moreschi G, et al. Cytotoxic T cells in cytomegalovirus infection: HLA-restricted T-lymphocyte and non-Tlymphocyte cytotoxic responses correlate with recovery from cytomegalovirus infection in bone-marrow-transplant recipients. N Engl J Med 1982; 307: 7-13.

9. Reusser P, Riddell SR, Meyers JD, Greenberg PD. Cytotoxic T-lymphocyte response to cytomegalovirus after human allogeneic bone marrow transplantation: pattern of recovery and correlation with cytomegalovirus infection and disease. Blood 1991; 78: 1373-1380.

10. Speich R, van der Bij W. Epidemiology and management of infections after lung transplantation. Clin Infect Dis 2001; 33 (Suppl 1): S58-S65.

11. Walker RC, Marshall WF, Strickler JG, Wiesner RH, Velosa JA, Habermann TM, et al. Pretransplantation assessment of the risk of lymphoproliferative disorder. Clin Infect Dis 1995; 20: 1346-1353. 
12. Cainelli $F$, Vento $S$. Infections and solid organ transplant rejection: a cause-and-effect relationship? Lancet Infect Dis 2002; 2: 539-549.

13. Gor D, Sabin C, Prentice HG, Vyas N, Man S, Griffiths PD, et al. Longitudinal fluctuations in cytomegalovirus load in bone marrow transplant patients: relationship between peak virus load, donor/recipient serostatus, acute GVHD and CMV disease. Bone Marrow Transplant 1998; 21: 597-605.

14. Ljungman $P$, Brand $R$, Einsele $H$, Frassoni $F$, Niederwieser $D$, Cordonnier C. Donor CMV serologic status and outcome of CMV-seropositive recipients after unrelated donor stem cell transplantation: an EBMT megafile analysis. Blood 2003; 102: 4255-4260.

15. Hebart H, Brugger W, Grigoleit U, Gscheidle B, Loeffler J, Schafer $\mathrm{H}$, et al. Risk for cytomegalovirus disease in patients receiving polymerase chain reaction-based preemptive antiviral therapy after allogeneic stem cell transplantation depends on transplantation modality. Blood 2001; 97: 2183-2185.

16. Gratama JW, van Esser JW, Lamers $\mathrm{CH}$, Tournay $\mathrm{C}$, Lowenberg B, Bolhuis RL, et al. Tetramer-based quantification of cytomegalovirus (CMV)-specific CD8+ T lymphocytes in T-cell-depleted stem cell grafts and after transplantation may identify patients at risk for progressive CMV infection. Blood 2001; 98: 1358-1364.

17. Grob JP, Grundy JE, Prentice HG, Griffiths PD, Hoffbrand AV, Hughes MD, et al. Immune donors can protect marrowtransplant recipients from severe cytomegalovirus infections. Lancet 1987; 1: 774-776.

18. Enright $H$, Haake R, Weisdorf $D$, Ramsay $N$, McGlave $P$, Kersey $\mathrm{J}$, et al. Cytomegalovirus pneumonia after bone marrow transplantation. Risk factors and response to therapy. Transplantation 1993; 55: 1339-1346.

19. Meyers JD, Flournoy N, Thomas ED. Risk factors for cytomegalovirus infection after human marrow transplantation. J Infect Dis 1986; 153: 478-488.

20. Noble S, Faulds D. Ganciclovir. An update of its use in the prevention of cytomegalovirus infection and disease in transplant recipients. Drugs 1998; 56: 115-146.

21. O'Brien JJ, Campoli-Richards DM. Acyclovir. An updated review of its antiviral activity, pharmacokinetic properties and therapeutic efficacy. Drugs 1989; 37: 233-309.

22. Meyers JD, Reed EC, Shepp DH, Thornquist M, Dandliker PS, Vicary CA, et al. Acyclovir for prevention of cytomegalovirus infection and disease after allogeneic marrow transplantation. N Engl J Med 1988; 318: 70-75.

23. Limaye AP, Corey L, Koelle DM, Davis CL, Boeckh M. Emergence of ganciclovir-resistant cytomegalovirus disease among recipients of solid-organ transplants. Lancet 2000; 356: 645-649.

24. Moretti S, Zikos P, Van Lint MT, Tedone E, Occhini D, Gualandi $F$, et al. Forscarnet vs ganciclovir for cytomegalovirus (CMV) antigenemia after allogeneic hemopoietic stem cell transplantation (HSCT): a randomised study. Bone Marrow Transplant 1998; 22: 175-180.

25. Emery VC. Prophylaxis for CMV should not now replace pre-emptive therapy in solid organ transplantation. Rev Med Virol 2001; 11: 83-86

26. Schmidt GM, Horak DA, Niland JC, Duncan SR, Forman SJ, Zaia JA. A randomized, controlled trial of prophylactic ganciclovir for cytomegalovirus pulmonary infection in recipients of allogeneic bone marrow transplants; The City of HopeStanford-Syntex CMV Study Group. N Engl J Med 1991; 324: 1005-1011.

27. Tanabe K, Tokumoto T, Ishikawa N, Koyama I, Takahashi $\mathrm{K}$, Fuchinoue S, et al. Comparative study of cytomegalovirus (CMV) antigenemia assay, polymerase chain reaction, serology, and shell vial assay in the early diagnosis and monitoring of CMV infection after renal transplantation. Transplantation 1997; 64: 1721-1725.

28. Humar A, Paya C, Pescovitz MD, Dominguez E, Washburn $\mathrm{K}$, Blumberg $\mathrm{E}$, et al. Clinical utility of cytomegalovirus viral load testing for predicting CMV disease in D+/R- solid organ transplant recipients. Am J Transplant 2004; 4: 644-649.

29. Ljungman $P$. Would monitoring $C M V$ immune responses allow improved control of CMV in stem cell transplant patients. J Clin Virol 2006; 35: 493-495.

30. Pantaleo G, Harari A. Functional signatures in antiviral Tcell immunity for monitoring virus-associated diseases. Nat Rev Immunol 2006; 6: 417-423.

31. Boeckh M, Leisenring W, Riddell SR, Bowden RA, Huang $\mathrm{ML}$, Myerson D, et al. Late cytomegalovirus disease and mortality in recipients of allogeneic hematopoietic stem cell transplants: importance of viral load and T-cell immunity. Blood 2003; 101: 407-414.

32. Walter EA, Greenberg PD, Gilbert MJ, Finch RJ, Watanabe KS, Thomas ED, et al. Reconstitution of cellular immunity against cytomegalovirus in recipients of allogeneic bone marrow by transfer of T-cell clones from the donor. N Engl $J$ Med 1995; 333: 1038-1044.

33. Reddehase MJ, Keil GM, Koszinowski UH. The cytolytic T lymphocyte response to the murine cytomegalovirus. II. Detection of virus replication stage-specific antigens by separate populations of in vivo active cytolytic $T$ lymphocyte precursors. Eur J Immunol 1984; 14: 56-61.

34. Martins SL, St John LS, Champlin RE, Wieder ED, McMannis J, Molldrem JJ, et al. Functional assessment and specific depletion of alloreactive human T cells using flow cytometry. Blood 2004; 104: 3429-3436.

35. Stanzani M, Orciuolo E, Lewis R, Kontoyiannis DP, Martins SL, St John LS, et al. Aspergillus fumigatus suppresses the human cellular immune response via gliotoxin-mediated apoptosis of monocytes. Blood 2005; 105: 2258-2265.

36. Sallusto F, Lenig D, Forster R, Lipp M, Lanzavecchia A. Two subsets of memory $T$ lymphocytes with distinct homing potentials and effector functions. Nature 1999; 401: 708712.

37. Hamann D, Kostense S, Wolthers KC, Otto SA, Baars PA, Miedema $F$, et al. Evidence that human CD8+CD45RA+ CD27- cells are induced by antigen and evolve through extensive rounds of division. Int Immunol 1999; 11: 10271033.

38. Kern F, Khatamzas E, Surel I, Frommel C, Reinke P, Waldrop SL, et al. Distribution of human CMV-specific memory T cells among the CD8pos. subsets defined by CD57, CD27, and CD45 isoforms. Eur J Immunol 1999; 29: 2908-2915.

39. Appay V, Dunbar PR, Callan M, Klenerman P, Gillespie GM, Papagno L, et al. Memory CD8+ T cells vary in differentiation phenotype in different persistent virus infections. Nat Med 2002; 8: 379-385.

40. Suni MA, Picker LJ, Maino VC. Detection of antigen-specific $\mathrm{T}$ cell cytokine expression in whole blood by flow cytometry. 
J Immunol Methods 1998; 212: 89-98.

41. Sinclair E, Black D, Epling CL, Carvidi A, Josefowicz SZ, Bredt BM, et al. CMV antigen-specific CD4+ and CD8+ T cell IFNgamma expression and proliferation responses in healthy CMV-seropositive individuals. Viral Immunol 2004; 17: $445-454$

42. Nomura LE, Walker JM, Maecker HT. Optimization of whole blood antigen-specific cytokine assays for CD4(+) T cells. Cytometry 2000; 40: 60-68.

43. Waldrop SL, Pitcher CJ, Peterson DM, Maino VC, Picker LJ. Determination of antigen-specific memory/effector CD4+ $T$ cell frequencies by flow cytometry: evidence for a novel, antigen-specific homeostatic mechanism in HIV-associated immunodeficiency. J Clin Invest 1997; 99: 1739-1750.

44. Bunde T, Kirchner A, Hoffmeister B, Habedank D, Hetzer R, Cherepnev G, et al. Protection from cytomegalovirus after transplantation is correlated with immediate early 1 -specific CD8 T cells. J Exp Med 2005; 201: 1031-1036.

45. Cwynarski K, Ainsworth J, Cobbold M, Wagner S, Mahendra $\mathrm{P}$, Apperley J, et al. Direct visualization of cytomegalovirusspecific T-cell reconstitution after allogeneic stem cell transplantation. Blood 2001; 97: 1232-1240.

46. Hebart H, Daginik S, Stevanovic S, Grigoleit U, Dobler A, Baur M, et al. Sensitive detection of human cytomegalovirus peptide-specific cytotoxic T-lymphocyte responses by interferon-gamma-enzyme-linked immunospot assay and flow cytometry in healthy individuals and in patients after allogeneic stem cell transplantation. Blood 2002; 99: 38303837.

47. Lacey SF, Gallez-Hawkins G, Crooks M, Martinez J, Senitzer D, Forman SJ, et al. Characterization of cytotoxic function of CMV-pp65-specific CD8+ T-lymphocytes identified by HLA tetramers in recipients and donors of stem-cell transplants. Transplantation 2002; 74: 722-732.

48. Ozdemir E, St John LS, Gillespie G, Rowland-Jones S, Champlin RE, Molldrem JJ, et al. Cytomegalovirus reactivation following allogeneic stem cell transplantation is associated with the presence of dysfunctional antigen-specific CD8+ T cells. Blood 2002; 100: 3690-3697.

49. Sester M, Sester U, Gartner B, Heine G, Girndt M, MuellerLantzsch N, et al. Levels of virus-specific CD4 T cells correlate with cytomegalovirus control and predict virus-induced disease after renal transplantation. Transplantation 2001; 71: 1287-1294.

50. Engstrand $M$, Lidehall AK, Totterman TH, Herrman B, Eriksson BM, Korsgren O. Cellular responses to cytomegalovirus in immunosuppressed patients: circulating CD8+ T cells recognizing CMVpp65 are present but display functional impairment. Clin Exp Immunol 2003; 132: 96-104.

51. Rauser G, Einsele H, Sinzger C, Wernet D, Kuntz G, Assenmacher M, et al. Rapid generation of combined CMV-specific CD4+ and CD8+ T-cell lines for adoptive transfer into recipients of allogeneic stem cell transplants. Blood 2004; 103: 3565-3572.

52. Hutchings PR, Cambridge G, Tite JP, Meager T, Cooke A. The detection and enumeration of cytokine-secreting cells in mice and man and the clinical application of these assays. J Immunol Methods 1989; 120: 1-8.

53. Ghanekar SA, Maecker HT. Cytokine flow cytometry: multiparametric approach to immune function analysis. Cytotherapy 2003; 5: 1-6.
54. Maecker HT, Rinfret A, D'Souza P, Darden J, Roig E, Landry $C$, et al. Standardization of cytokine flow cytometry assays. BMC Immunol 2005; 6: 13.

55. Suni MA, Dunn HS, Orr PL, de Laat R, Sinclair E, Ghanekar $\mathrm{SA}$, et al. Performance of plate-based cytokine flow cytometry with automated data analysis. BMC Immunol 2003; 4: 9.

56. Kern F, Surel IP, Brock C, Freistedt B, Radtke H, Scheffold A, et al. T-cell epitope mapping by flow cytometry. Nat Med 1998; 4: 975-978.

57. Maecker HT, Maino VC. Analyzing T-cell responses to cytomegalovirus by cytokine flow cytometry. Hum Immunol 2004; 65: 493-499.

58. Vaz-Santiago J, Lule J, Rohrlich P, Jacquier C, Gibert N, Le Roy $\mathrm{E}$, et al. Ex vivo stimulation and expansion of both CD4(+) and CD8(+) T cells from peripheral blood mononuclear cells of human cytomegalovirus-seropositive blood donors by using a soluble recombinant chimeric protein, IE1-pp65. J Virol 2001; 75: 7840-7847.

59. Nylander S, Kalies I. Brefeldin A, but not monensin, completely blocks CD69 expression on mouse lymphocytes: efficacy of inhibitors of protein secretion in protocols for intracellular cytokine staining by flow cytometry. J Immunol Methods 1999; 224: 69-76.

60. Maecker HT, Dunn HS, Suni MA, Khatamzas E, Pitcher CJ, Bunde $T$, et al. Use of overlapping peptide mixtures as antigens for cytokine flow cytometry. J Immunol Methods 2001; 255: 27-40 